\title{
The A148T variant of CDKN2A gene in bladder cancer
}

\author{
E Borkowska ${ }^{1 *}$, A Jedrzejczyk ${ }^{2,4}$, A Kruk ${ }^{3}$, M Traczyk ${ }^{1}$, M Pietrusiński ${ }^{1}$, P Marks ${ }^{4}$, B Kaluzewski \\ From Annual Conference on Hereditary Cancers 2009 \\ Szczecin, Poland. 10-11 December 2009
}

\section{Background}

Cancer of the urinary bladder is a common malignant disease in Poland. Molecular genetic alterations play a key role in bladder cancer carcinogenesis. Understanding genetic events that lead to initiation and progression of bladder cancer remains an important challenge in urological research.

\section{Materials and methods}

44 lesions were determined to be non-invasive tumors (pTa), whereas 36 tumors were invasive (pT1-T4). Tumor grade was noted low (G1) in 46 cases and high (G2-3) in 34 cases. DNA samples were evaluated for CDKN2A mutations with the use of MSSCP and sequencing method.

\section{Results}

We found common polymorphic variants reported in the literature at codon 148 in exon 2 (Arg148Thr) and at nucleotides 500 and 540 in the 3'untranslated region which were not considered to be functional variants. We compared the obtained frequencies for the particular CDKN2A variants with the control group for the Polish population examined by Debniak and colleagues (Cancer Research 2005) and we found a significant difference in A148T polymorphism occurrence in the group of the bladder cancer patients ( $G$ test, table 2 $\times 2: \mathrm{N}_{\text {BLAdDER CANCER }}=80, \mathrm{~N}_{\text {CONTROL }}=1210, \mathrm{G}=10.214$, $\mathrm{p}<0.01)$. The Nt 500c $>$ g, Nt540c $>$ t polymorphisms recorded in the group of the bladder cancer patients in our study is not different from those recorded in the control group.

\section{Conclusion}

The A148T variant of $C D K N 2 A$ gene seems to be associated with an increased risk of bladder cancer development.

\section{Author details \\ 'Medical University of Łodz, Chair of Clinical and Laboratory Genetics, Poland. ${ }^{2} 2^{\text {nd }}$ Clinic of Urology Medical University of $Ł o d z$, Poland. \\ ${ }^{3}$ Department of Ecology and Vertebrate Zoology, University of Łodz, Poland. \\ ${ }^{4}$ Department of Urology, John Paul II Regional Hospital Belchatow, Poland.}

Published: 1 June 2011

\section{doi:10.1186/1897-4287-9-S2-A11}

Cite this article as: Borkowska et al:: The A148T variant of CDKN2A gene in bladder cancer. Hereditary Cancer in Clinical Practice 2011 9(Suppl 2): A11

Submit your next manuscript to BioMed Central and take full advantage of:

- Convenient online submission

- Thorough peer review

- No space constraints or color figure charges

- Immediate publication on acceptance

- Inclusion in PubMed, CAS, Scopus and Google Scholar

- Research which is freely available for redistribution

\section{BioMed Central}

